\title{
The Carrot or the Stick: Self-Regulation for Gender-Diverse Boards via Codes of Good Governance
}

\author{
Heike Mensi-Klarbach ${ }^{1} \cdot$ Stephan Leixnering ${ }^{2} \cdot$ Michael Schiffinger $^{3}$
}

Received: 12 January 2019 / Accepted: 28 October 2019 / Published online: 14 November 2019

(c) The Author(s) 2019

\begin{abstract}
Scholars have emphasized the potential of self-regulation, realized through 'codes of good governance', to improve gender diversity on boards. Yet, unconvinced of the effectiveness of this self-regulation, many regulators have implemented mandatory quota laws. Our study sheds light on this dilemma. Seeking to broaden our conceptual knowledge of how such 'codes' work in the specific case of gender diversity on boards, we ask: Under which conditions is self-regulation via voluntary principles of good governance effective? Expanding recent institutional-theory perspectives from the literature of women on boards, we show that, in the case of Austria, self-regulation via code recommendations is ineffective unless supported by additional forces. The primary reason for this, we argue, is that nominators do not expect benefits from gender-diverse boards. Furthermore, non-compliant companies face little pressure to change due to the small number of companies that have already adopted respective code recommendations. We identify two potential alternatives to boost the effectiveness of voluntary self-regulation for gender-diverse boards: First, the introduction of concrete targets for female representation and the public monitoring of fulfillment; and, second, the establishment of a credible threat that mandatory quotas will be imposed if diversity goals are not achieved. Drawing on longitudinal data from 2006 to 2016 on listed and state-owned companies in Austria, we give an empirical account of the conditions that assure effective self-regulation. Arguing that codes suffer from what we call 'opportunity bias', we conclude that political goals (such as gender equality) based on ethical rather than instrumental considerations are unlikely to be effectively implemented solely by codes of good governance.
\end{abstract}

Keywords Women on boards $\cdot$ Gender diversity $\cdot$ Codes of good governance $\cdot$ Self-regulation $\cdot$ Institutional theory

\section{Introduction}

Heike Mensi-Klarbach

heike.mensi-klarbach@wu.ac.at

Stephan Leixnering

stephan.leixnering@wu.ac.at

Michael Schiffinger

michael.schiffinger@wu.ac.at

1 Department of Management, WU Vienna University of Economics and Business, Welthandelsplatz 1, 1020 Vienna, Austria

2 Research Institute for Urban Management and Governance, WU Vienna University of Economics and Business, Welthandelsplatz 1, 1020 Vienna, Austria

3 Interdisciplinary Institute for Management and Organizational Behavior, WU Vienna University of Economics and Business, Welthandelsplatz 1, 1020 Vienna, Austria
Across the world, women remain a minority on corporate boards (Brieger et al. 2019; Carrasco et al. 2015; Grosvold et al. 2016). While a growing body of studies indicates some positive effects of gender-diverse boards on company performance, it cannot be denied that, overall, the empirical evidence to date is inconclusive (for overviews see Adams et al. 2015; Kirsch 2017; Post and Byron 2015). Indeed, the slow rise in the number of female board members suggests that nominators are unconvinced of the benefits of gender-balanced boards. Increasingly, gender diversity is positioned as an ethical issue of social justice and thus a matter to be addressed by political decision-makers (European Commission 2016; Ferreira 2015; Stein and van der Vlies 2014; World Economic Forum 2017). Affirming that the low proportion of women in top positions clearly contradicts the democratic principle of equality, governments in various Western countries have constituted gender diversity 
on boards as a political goal, promoting the introduction of gender diversity as a principle of corporate governance (Gabaldon et al. 2017b; Klettner et al. 2016; Terjesen et al. 2015), enshrined in voluntary 'codes of good governance' ${ }^{1}$ (Aguilera and Cuervo-Cazurra 2004, 2009).

Since around 2004, national codes of good governance have increasingly come to feature provisions recommending that gender diversity should be considered when nominating directors (Gabaldon et al. 2017b). Voluntary by definition, these collections of best practices are implemented through self-regulation: Their comply-or-explain logic offers companies the flexibility to either adopt recommended practices or explain why these are unsuitable for them (Boyd 1996; Klettner et al. 2016; Terjesen et al. 2015). Yet many governments have recently withdrawn their support for codes, turning from self-regulation to coercive regulation via legislative quotas (Labelle et al. 2015). By 2018, for example, nine European countries ${ }^{2}$ followed the example of Norway, a forerunner in this regard, in implementing mandatory quotas (Mensi-Klarbach and Seierstad 2019). As their primary motivation, regulators argued that voluntary self-regulation had proven ineffective in raising gender diversity on boards (Grosvold et al. 2007; see also Deutscher Bundestag 2014).

The literature on women on boards, however, does not support the general assertion that self-regulation of gender diversity on boards is always ineffective (Sojo et al. 2016). On the contrary, empirical evidence indicates that voluntary approaches can successfully increase the proportion of female directors (European Women's Lobby 2012; for Australia, see Klettner et al. 2016; for the UK, see Doldor 2017). In addition, scholars even argue that, compared to legislative quotas, self-regulation is more likely to foster a cultural shift towards gender equality as well as to transform prevailing gender roles favoring men in board positions (Iannotta et al. 2016; Klettner et al. 2016). While previous research suggested that mandatory quotas could initiate cultural change (Wang and Kelan 2013), recent findings are more pessimistic. For example, the quota in Norway was found to have "very little discernible impact on women in business beyond its direct effect on the women who made it into boardrooms" (Bertrand et al. 2019, p. 191). Moreover, mandatory quotas bear the risk of evoking strong resistance by companies, who may be inclined to follow "the letter rather than the spirit of the law" (Boyd 1996, p. 12), leading to the appointment of 'token women' (Du Plessis et al. 2014) as well as few 'golden skirts' (Seierstad and Opsahl 2011), i.e., women who acquire numerous board positions. Hence, we find here

\footnotetext{
${ }^{1}$ We sometimes refer to 'codes of good governance' as 'codes' for better readability.

2 Austria, Belgium, France, Germany, Iceland, Italy, Netherlands, Portugal, and Spain.
}

a basic contradiction: While scholars have emphasized the potential of self-regulation to improve gender diversity on boards, many regulators have turned to mandatory quotas in the belief that voluntary self-regulation has failed.

The aim of the current study is to shed light on this dilemma by broadening our conceptual knowledge of how voluntary codes impact gender diversity on boards. More specifically, we ask: Under which conditions is self-regulation via principles of good governance effective? In our analysis we follow the example of recent studies in the scholarly field of women on boards by applying an institutionaltheory lens to the topic (Carrasco et al. 2015; Gregorič et al. 2017; Grosvold et al. 2016; Perrault 2015; Terjesen et al. 2015). We focus on two factors identified in the literature as driving the diffusion of new practices (Kennedy and Fiss 2009) and argue that these also promote the adoption of practices recommended by codes: First, when companies are motivated by the perceived likelihood of benefits such as increased reputation, prestige, or profits; and second, when they respond to the perceived danger of losses incurred by non-adoption.

While gender diversity on boards is frequently mentioned in codes of good governance across the world (Gabaldon et al. 2017a, b), overall the numbers of female directors remain low. This indicates that nominators are skeptical of potential gains from gender-diverse boards and do not fear losses resulting from non-diverse boards. In addition, we argue that the overall number of adopters is too low to initiate those pressures usually imposed by code mechanisms on remaining non-adopters. Therefore, our key point is that, due to the insufficient number of companies that expect benefits from adoption and hence (in complying with code recommendations) initiate pressures on non-adopters, additional forces must be exploited to ensure the success of self-regulation via codes. We suggest that code provisions can generate these forces by supplementing best-practice recommendations on gender diversity with measurable outcomes, i.e., targets for female representation and the public monitoring of fulfillment. Further, we assume that regulators can trigger additional pressures by threatening to legislate mandatory quotas.

Empirically, we focus on one particular institutional environment, namely the case of Austria, where voluntary self-regulation has taken different forms over time. Drawing on longitudinal data from 2005 to 2016 on listed and stateowned companies, we test three hypotheses on the effects of self-regulation via voluntary codes on the proportion of female board members. Using a log-linear Poisson model, we find that code recommendations have indeed been ineffective in Austria unless supported by other forces. In particular, our analysis shows that the inclusion of specific targets for the proportion of female directors and the threat of 
legislated quotas can serve to pressurize nominators, resulting in more gender-diverse company boards.

Our study thus makes a threefold contribution to the literature on women on boards: First, by giving an empirical account of the conditions under which the self-regulation of gender diversity on boards via codes of good governance is effective. Second, we identify two potential ways of boosting the impact of voluntary self-regulation towards gender diversity on boards, and discuss the inherent limits and opportunities of these approaches. Third, and perhaps of greatest interest, we argue that codes of good governance suffer from what we call an 'opportunity bias', i.e., their underlying mechanisms require a sufficient number of companies to implement a practice because of expected gains, thereby triggering pressures on non-adopters. Therefore, we conclude that political goals such as gender equality based on ethical rather than instrumental considerations are unlikely to be effectively implemented by codes alone.

The remainder of this article is structured as follows: in the next section we outline the conceptual background to our research and develop our hypotheses. This is followed by a presentation of our study design, the Austrian case, as well as data, our method, and findings. Finally, we discuss these findings, reflect on implications for policy-making, and address limitations.

\section{Conceptual Background and Hypotheses}

\section{Gender-Diverse Boards and Codes of Good Governance}

The self-regulation of gender diversity on boards is usually realized by means of voluntary codes of good governance (Gabaldon et al. 2017b). Early codes such as that proposed by the UK's Cadbury Report of 1992 were drawn up as a reaction to business scandals. Originally issued by representatives of the capital market to avoid managerial misuse of power, primarily at the expense of shareholders, codes recommend rules of best practice such as rejecting the duality of the offices of CEO and chairperson as well as emphasizing the supervisory role of non-executive directors (Boyd 1996). In the mid-2000s, when national codes of good governance had already spread around the globe (Aguilera and Cuervo-Cazurra 2009), issuers started to add provisions to improve gender diversity on boards (Smith 2014). Today a clear majority of codes includes recommendations for the gender-diverse composition of boards (for Europe, see Gabaldon et al. 2017a, b). Codes usually allow for some degree of flexibility by applying the comply-orexplain logic, which requires companies to publicly report on their compliance with code recommendations or state reasons for non-compliance (Seidl 2007).

\section{Reasons for Compliance with Best-Practice Recommendations}

While a mandatory gender quota is clearly a coercive pressure, voluntary self-regulation via codes draws on a different mechanism. The classical institutional model of practice implementation suggests two separate rationales for organizations to adopt practices (Tolbert and Zucker 1983): While early adopters follow an economic imperative, viewing the practice as technically effective ('efficiency'), later adopters respond to the social imperative of 'legitimacy', i.e., they wish to comply with the expectations of their environments (DiMaggio and Powell 1983; see also Gregorič et al. 2017). More recent work, however, argues that such a segregation of economic and social logics is not only empirically difficult but also conceptually problematic as efficiency may be socially expected, thereby also representing a source of legitimacy (Höllerer 2013; Lounsbury 2007; Meyer 2004). At the same time, other scholars construe legitimacy as a key social resource granting access to economic resources and thus contributing to efficiency (Staw and Epstein 2000; see also Gregorič et al. 2017; Perrault 2015). Rethinking the classical model of practice implementation, Kennedy and Fiss (2009) claimed that early adopters are motivated by the perceived opportunity of achieving gains, whether economic or social, while later adopters respond to the perceived danger of incurring losses.

This latter concept, we argue, is also apt to explain what drives companies to follow best-practice recommendations in national codes of good governance. Initially, a few companies comply because they interpret a recommended practice as an opportunity to achieve gains such as increased reputation, prestige, or profits. Later, more and more companies adopt the practice because of pressures caused by the sheer number of complying companies. Such 'bandwagon' pressures, which were originally studied in the diffusion of management fashions, arise from a sufficient number of early adopters ('adoption threshold') triggering a positive feedback loop: "[I]ncreases in the number of adopters raise bandwagon pressures, and raised bandwagon pressures cause the number of adopters to grow" (Abrahamson and Rosenkopf 1993, p. 488). Clearly, non-adopters wish to avoid competitive disadvantages due to their non-compliance. This mechanism, in particular, we further argue, links to what has been identified as key to the effectiveness of voluntary self-regulation by drawing on the underlying motivation for compliance of later adopters, which is "assumed to be the fear of public exposure and criticism of firms that deviate from the code" (Boyd 1996, p. 172). 


\section{Self-Regulation via Codes Alone is Ineffective}

Despite mixed evidence on their economic effects (Adams et al. 2015; Kirsch 2017; Post and Byron 2015), scholars have argued that business environments are increasingly in favor of gender-diverse boards (Terjesen et al. 2009), with most actors now decrying "the lack of legitimacy of homophilous (e.g., all-male) boards" (Perrault 2015, p. 149). Literature on women on boards also highlights the societal demand for gender equality and the political goal of gender-diverse boards as external pressures that can potentially shape the nomination practices of organizations (Gregoric et al. 2017). Nevertheless, the proportion of female directors has generally remained low in many countries (Brieger et al. 2019; Carrasco et al. 2015; Grosvold et al. 2016).

From a conceptual perspective, we thus conclude that nominators hardly expect gains from gender-diverse boards, even if recommended by codes of good governance. The number of companies that follow respective code recommendations fails to meet the adoption threshold, and hence is too low to trigger bandwagon pressures on non-adopters. Thus, we can formulate our first hypothesis as follows:

(H1) Voluntary self-regulation of gender diversity on boards that solely draws on recommendations in codes of good governance will not be effective in increasing the proportion of female directors.

In the absence of a sufficient number of adopters perceiving self-regulation as an opportunity to achieve gains and thus initiating bandwagon pressures on non-adopters, we argue that self-regulation via codes must exploit additional forces to be effective. Echoing recent voices in the debate on women on boards skeptical of whether societal demands alone were sufficiently powerful to raise gender diversity (e.g., Gregorič et al. 2017), we deny that code provisions alone can increase female representation in higher echelons. At the same time, we argue that voluntary self-regulation can still be effective when additional forces place pressures on non-adopters.

\section{A Focus on Specific Outcomes Triggers Pressures}

Arguing for 'radical' solutions in the implementation of policies, scholars have previously suggested moving away from a procedural focus on recommended practices to a results-oriented perspective (Jewson and Mason 1986). This idea is aligned with the basic control philosophy of management, which holds that objectives must be measurable and specific in order to be achieved (Drucker 1954). There is no doubt that provisions within codes usually suggest practices in a rather procedural way (e.g., board election procedures, information flow between board and management) unrelated to specific outcomes. In this respect, gender diversity provisions differ from most other code recommendations, whereby altered nomination practices should result in changed board compositions. While compliance in terms of gender diversity is easily measurable, i.e., a higher ratio of female directors, most codes do not address this, preferring to remain unspecific about targeted outcomes: They adopt vague formulations such as that gender diversity should be 'considered appropriately' in the nomination of board members (Mensi-Klarbach 2017). Such ambiguous language in regulatory provisions serves to hamper equality by encouraging divergent interpretations of the meaning of 'diversity' in relation to boards (Edelman 2016). Recommendations remain 'incomplete' in that they do not provide a clear standard as point of reference to evaluate and publicly monitor compliant or deviant behavior by companies (Klettner et al. 2016; Seidl 2007).

The beneficial effect of target-setting has long been recognized in the management literature, perhaps most famously formulated in goal-setting theory (Locke 1968; Locke and Latham 2002). The underlying assumption of this theory is that "goals direct attention, effort, and persistence towards a goal-relevant outcome" (Wood et al. 2013, p. 91). In addition, it implies that improvements in the goal-relevant outcome are most likely when goals are not only specific but also complemented by feedback on goal attainment (Ashford and De Stobbeleir 2013; see also Mento et al. 1987). Recently, scholars have argued that the idea of goal setting, i.e., defining "a standard of expected achievement on a specific criterion", also underlies the definition of targets for female representation on boards, which "focus attention and accountability on outcomes" (Sojo et al. 2016, p. 520). This argument implies that goal-setting theory, originally centered on the motivation of individuals to perform better (Locke and Latham 2013), can also be applied to the field-level goals of organizations. The UK example indicates that such an approach may be effective: Here an independent committee sets targets for gender diversity on boards in addition to code recommendations and publicly reports on companies' progress (Davies Review 2011-2015; HamptonAlexander Review since 2016, see Doldor 2017).

Drawing on this assertion, we argue that the establishment of targets for gender diversity on boards imposes pressures on companies to adopt respective code recommendations. The setting of clearly defined standards reduces interpretative discretion when assessing companies' voluntary compliance with the otherwise abstract goal of gender diversity. In addition, public monitoring of companies' progress serves as a feedback mechanism to identify compliant and deviant behavior of companies in a binary hit-or-miss logic. Therefore, we expect that supplementing vague best-practice recommendations on gender diversity with measurable outcomes and feedback on their fulfillment will generate additional pressures on nominators to appoint more women. 
Companies view public criticism of their non-compliance as a potential loss. We thus hypothesize that:

(H2) Voluntary self-regulation of gender diversity on boards that draws on recommendations in codes of good governance as well as specific targets for outcomes and their public monitoring will be effective in increasing the ratio of female directors.

\section{The 'Shadow of Hierarchy' Triggers Pressures}

Self-regulation essentially draws on the idea of voluntary collaboration rather than coercion (Hart 2010). In attempting to distinguish voluntary self-regulation from legislative regulation, the governance literature has identified 'cooperation' and 'hierarchy' as alternative regulatory modes (Rhodes 1996; Scharpf 1997). Whereas hierarchy is based on coercive enforcement via laws and directives, cooperation involves bargaining among involved actors and, in particular, provides the option of non-compliance. While codes of corporate governance are clearly oriented on the latter mode, they have also been regarded "as an attempt to maintain a system of self-regulation in the face of the threat of legislated control" (Boyd 1996, p. 172, italics added). Thus companies' motivation for voluntary compliance with codes is neither derived from the imposition of legislative authority nor from its total absence, but from the potential imposition of regulatory authority and the wish to avoid this outcome (Börzel 2008; Mayntz 2006; Schuppert 2007). Voluntary adoption, therefore, happens under the condition of potential rather than actual coercion. Such voluntary cooperation by companies under a considerable degree of potential legislative coercion has been described as acting under the "shadow of hierarchy' (Scharpf 1997; see also Peters and Pierre 2016; Steurer 2013). In particular, this topic has been discussed within the public-policy literature on multilevel governance in the European Union (Héritier and Lehmkuhl 2008).

Regarding gender diversity on boards, we now draw on research from other countries, namely Sweden (Bohman et al. 2012), France (Singh et al. 2015), Australia (Klettner et al. 2016), as well as the UK (Grosvold et al. 2007; Sealy and Vinnicombe 2013), arguing that the emergence of a threat due to regulators' public sympathizing with legislative board quotas has a positive effect on female representation. We suggest that in such particular cases of self-regulation under the 'shadow of hierarchy', the mere threat of the regulator's "interference in what [companies] considered strictly business issues" (Bohman et al. 2012, pp. 94-95) places considerable pressures on nominators. The retention of non-diverse boards may result in the regulator imposing mandatory board quotas. We argue, however, that companies try to signal that a shift to mandatory board quotas is unnecessary and that self-regulatory forces (instigated by codes) are sufficient. It can be assumed that the regulator's threat to legislate mandatory quotas triggers additional pressures on nominators to appoint more women, as such legislation would result in a partial or complete loss of companies' discretionary freedoms. This leads to our third hypothesis:

(H3) Voluntary self-regulation of gender diversity on boards under the threat that the regulator might implement a legislative board quota will be effective in increasing the ratio of female directors.

\section{Empirical Setting:The Case of Austria}

The history of voluntary self-regulation of gender diversity on Austrian boards started in 2008 when the country's code of corporate governance recommended for the first time that appropriate consideration be given to gender diversity in [supervisory ${ }^{3}$ ] board nominations (Rule 42). The Austrian code was originally drawn up in 2002 by various representatives of the capital market such as listed firms, investors, the Vienna Stock Exchange, and the Austrian Institute of Auditors (Schenz and Eberhartinger 2002). From 2004 the Vienna Stock Exchange required all companies listed on its prime market to subscribe to the comply-or-explain principle and to publish an annual report on corporate governance. In 2008 the Austrian parliament codified these requirements in the Austrian Commercial Act (Article 243b). Subsequently, listed companies have been legally required to publish annual corporate governance reports. Compliance with code recommendations, however, remains voluntary.

In the 2000s gender provisions were implemented in national codes of corporate governance in many other European countries (Gabaldon et al. 2017a, b). Mandatory quotas also gained momentum in the late 2000s when several European regulators followed the example of Norway, the pioneer in this regard (Seierstad et al. 2017; Terjesen et al. 2015). In 2010 the European Commission announced the development of an EU-wide regulation of gender diversity on boards. The Commission's Vice-President, Viviane Reding, said that, since all calls for voluntary self-regulation had failed to deliver, the commission was prepared to introduce mandatory quotas (European Commission 2010). In 2011 the European Parliament endorsed this approach in a resolution on the issue (European Parliament 2011); and in 2012 the Commission published a draft directive (European Commission 2012). Although this initiative did not in fact lead to any further legislative steps, these developments at the European level contributed to the lively public debate on

\footnotetext{
3 Austria follows the German approach of a two-tier board system (executive and supervisory boards: Doralt et al. 2012; see also Davies 2000).
} 
how to achieve gender diversity on boards. Intense media coverage placed considerable pressure on companies as well as national regulators to decide whether to stick to voluntary self-regulation or turn to mandatory board quotas.

From 2010 the Austrian Federal Minister for Women and the Civil Service, Gabriele Heinisch-Hosek, began to argue for the introduction of specific targets in the Austrian code recommendation on gender diversity on boards. At the height of heated EU-wide discussions on the implementation of mandatory board quotas, she courted controversy in Austria by announcing the implementation of mandatory quotas if voluntary self-regulation proved insufficient. ${ }^{4}$ As a reaction to the code issuers' decision in 2012 not to include any targets in their revised code, the regulator withdrew support for the self-regulation of gender diversity on boards, imposing a legal requirement in the Austrian Corporate Act (Article 87) that gender diversity be appropriately considered. However, the regulator stopped short of introducing mandatory quotas for listed companies and continued with the vague formulation of the relevant provision

Parallel to these developments, in 2012 the Austrian government established a voluntary regulatory framework for state-owned companies and implemented a 'public' code of good governance (Bundeskanzleramt 2012), which recommended working to achieve gender equality on supervisory boards (Rule 11.2.1.2). In addition, the government required state-owned companies to publish annual corporate governance reports clearly indicating the ratio of women on supervisory boards as well as to subscribe to the complyor-explain principle. One year earlier, the government had committed itself to voluntary targets for female representation on the supervisory boards of all state-owned companies, namely $25 \%$ by 2013 and 35\% by 2018 (Österreichische Bundesregierung 2011). To document progress made, since 2012 the government has published the ratios of women on these supervisory boards.

\section{Method}

\section{Data}

\section{Sample}

Our sample consists of the full population of Austrian companies that took part in voluntary self-regulation to increase

\footnotetext{
${ }^{4} 137$ newspaper articles on this issue were published from 2010 to 2012 by the leading Austrian newspapers Der Standard and Die Presse (see method section). For example, on April 16, 2010, the minister is quoted as saying that she does not see how a voluntary approach can work: "In the year 2010, women don't get appointed to top management positions unless it suits the men" (authors' translation)
}

gender diversity on boards. More precisely, we focus on two separate sets of companies: first, companies listed on the prime market of the Vienna Stock Exchange, which were addressed by recommendations of the Austrian code; and second, state-owned companies in which the Federal Republic of Austria holds a direct share of at least $50 \%$, which were addressed by the Austrian 'public' code as well as the government's voluntary commitment to specific targets. Drawing on the Austrian commercial register, we collected data for the years 2006 to 2016 on supervisory-board members as well as companies. Our sample includes 65 listed companies (439 years in total) and 61 state-owned companies (527 years in total). ${ }^{5}$

\section{Models}

In a first set of models, we separately examined the main effects of Recommendation and Threat on listed companies and Targets on state-owned companies regarding the proportion of female board members while taking account of Year, Board size and Company size, average Board tenure and whether the industry to which a respective company belongs has an employment base of more than $50 \%$ women ('Female' industry). In a second set of models, we explored potential interaction effects between these control variables and the three self-regulations, including the level of State ownership for state-owned companies (see below for detailed descriptions of each variable operationalization).

\section{Dependent Variable}

Our study investigates the conditions under which voluntary self-regulation of gender diversity on boards via code recommendations may be effective. We argue that additional forces are required to amplify existing, yet limited, legitimacy pressures in order to render self-regulation effective, and that these forces vary between different periods of self-regulation. Similar to Gregorič et al. (2017; following Ingram and Simons 1995), we argue that the effectiveness of voluntary self-regulation can be measured by an increase in that which is demanded, i.e., a gender-diverse board composition. Specifically, our dependent variable is the proportion of female supervisory-board members (see also Perrault 2015), i.e., the number of female board members divided by

\footnotetext{
5 The fact that the number of years is here lower than the number of companies multiplied by the 11 years of the observation period 20062016 can be attributed to changes in the sets of companies (e.g., later listings, de-listings, mergers, and insolvencies of listed companies, especially after 2008; also the establishment and dissolution of stateowned companies or changes in the percentage of the government's stake in these companies).
} 
the total number of board members in a given company and year (shareholder representatives only ${ }^{6}$ ).

\section{Explanatory Variables}

We measure the effect of voluntary self-regulation by comparing the proportions of female board members before and after implementation (similar to the approach of Sojo et al. 2016), while accounting for the linear trend during the whole relevant period (see below).

Recommendation To test the effectiveness of self-regulation based solely on the Austrian code recommendation for gender diversity introduced in 2008, we measure the change in the proportion of female board members in listed companies in the periods after (2009-2010) and before (20062008) implementation of this form of self-regulation.

Targets Self-regulation via code recommendation, supplemented by specific targets for outcomes and public monitoring of fulfillment, was imposed on state-owned companies in 2011. To test the effectiveness of this approach, we compare changes in the proportion of female board members in state-owned companies in the period 2011-2016 (after the introduction of voluntary targets) with the preceding period 2006-2010.

Threat To test the effect of the threat that the government might introduce a mandatory quota, we examine changes in the proportion of female board members in listed companies in a period when public debate on the implementation of mandatory quotas was exceptionally intense. We conceive this threat as the heated debate on quota implementation conducted in Austria's two leading quality newspapers, one of which is politically left-of-center and the other right-of-center (see "Appendix 1"). Accordingly, we compare changes in the proportion of female board members in listed companies in the period of 2011-2012, when public discussions were exceptionally lively, with the previous period 2009-2010, which was before the EU Commission and the Austrian government expressed interest in mandatory quotas.

\section{Control variables}

Previous research has shown that the effect of self-regulation via codes is potentially confounded with a general

\footnotetext{
${ }^{6}$ Under Austrian law, companies must implement a two-tier board system (see footnote 1) and adopt the principle of codetermination, i.e., participation of employee representatives in supervisory boards (Doralt et al. 2012; see also Davies 2000). However, Austrian code provisions for gender diversity only address shareholder representatives on supervisory boards (for a similar empirical context, see Gregorič et al. 2017).
}

trend towards increased female representation on boards. For this reason, we include Year as a covariate (Sojo et al. 2016). In addition, we consider several company-related variables: First, we control for Board size, i.e., the total number of shareholder representatives on supervisory boards, as the percentage of women on boards has been found to be positively correlated with this variable (Terjesen et al. 2009). We also control for Company size (i.e., the number of employees, logarithmized to reduce the influence of outliers), which is mentioned as a potential determinant of gender diversity on boards, indicating a positive relation between firm size and female representation on boards (Grosvold et al. 2007; Hillman et al. 2007). At industry level, we control for whether a respective company belongs to a 'Female' industry, i.e., where more than $50 \%$ of the workforce is female, as firms operating in such sectors are more likely to have gender-diverse boards (Hillman et al. 2007). ${ }^{7}$ We also control for the average length of Board tenure (as of 2016), as longer tenure implies lower turnover and thus slower progress towards gender diversity. Finally, we control for the degree of State ownership in the set of state-owned companies, assuming that nominations by state agencies are more likely to be affected by the government's commitment to gender-diverse boards than those by other co-owners. This variable is divided into three categories, i.e., minimum ownership of $50 \%$ as reference category; $>50-75 \%$ ownership; $>75-100 \%$ ownership.

\section{Data Analysis}

Our analyses had to take two factors into account. First, as our observations consist of multilevel data (i.e., years nested within companies), we could not rely on an analytical method that assumes independent data such as OLS regression. Second, direct calculation of the proportion of female board members for each year would result in a criterion variable that is extremely skewed, zero-inflated (40\% of all cases), and severely affected by outliers. Thus we adopted a generalized estimating equation (Zeger and Liang 1986) log-linear Poisson model with year as repeated level 1 effect within companies as level 2 units (exchangeable correlation structure and robust covariance matrix estimator; Williams 2000). While the immediate outcome variable is the number of female supervisory-board members (shareholder representatives only), we used the logarithm of the total number

\footnotetext{
${ }_{7}$ We identified these industries based on data published by the Main Association of Austrian Social Security Institutions (Sozialversicherung 2016), which follows the NACE categorization system of the European Union: accommodation and food service activities; real estate activities; professional, scientific and technical activities; public administration and defense; compulsory social security; education, human health and social work activities.
} 
of board members as a so-called 'offset variable' to enable us to model the dependent variable reported above, i.e., the proportion (rather than the number) of female board members (Agresti 2007, p. 82).

We tested our hypotheses by examining the effect of a dichotomous variable representing the periods before and after implementation of self-regulation on the proportion of female board members (2009-2010 vs. 2006-2008 for Recommendation and 2011-2012 vs. 2009-2010 for Threat, based on listed companies; 2011-2016 vs. 2006-2010 for Targets, based on state-owned companies) while also taking account of the linear trend and the abovementioned control variables. The proportion of female board members is thus modeled with the following predictors: The periods before and after introducing self-regulation, Year, the number of board members (Board size), the (logarithmized) number of employees (Company size), average Board tenure (i.e., how many years on average members have been on the board), and whether the company operates in an industry with more than $50 \%$ female employees ('Female' industry).

In addition to these main effect models, we calculated a second set of models to investigate the interactions between self-regulations and the control variables. Additional analyses included a comparison of the estimates of Recommendation, Targets, and Threat with the level 2 variable (i.e., company) as a random effect to those with company as a fixed effect. In addition to being a check of model robustness (i.e., whether the identified effects of the measures still apply in the fixed effect models), this comparison also helps detecting model misspecifications and potential endogeneity problems (Hausman test, e.g., Antonakis et al. 2010, p. 1093). Given that logistic rather than linear models were applied, a Chi square statistic (with one degree of freedom) was calculated by dividing the squared difference between the estimators for fixed and random effects models by the difference between the respective squared standard errors (Staub 2009, p. 1838). The statistical models were calculated using the software IBM SPSS Statistics 20. All continuous predictors were grand-mean centered before conducting the analyses. One limitation to our analysis is that the main predictor relies on a comparison of time periods. Another limitation is that our control variables do not include demographic attributes of nominators that may also influence the effectiveness of voluntary self-regulation for gender diversity on boards. Including attributes of supervisory-board members could have partly accounted for such an effect, as the supervisory board may propose candidates even if their nomination is a task to be performed by the general meeting of shareholders. Further, as with most observational studies on the implementation of a specific measure, there is no counterfactual setting to assess the measure's effect more precisely and reliably.

\section{Findings}

The following table (Table 1) shows the descriptives and intercorrelations for all variables used in the analyses for state-owned as well as listed companies. For illustrative purposes we also include the proportion of female board members calculated directly.

The following graphs (Fig. 1) show the development of the proportion of female board members in listed and state-owned companies. The bars represent the value range between the first and third quartile (i.e., the middle $50 \%$ of the sample), while the large darker dots represent the mean values for the respective year.

Previous studies have revealed within-country differences in gender diversity on boards, with diversity being higher in the public than in the private sector (Brieger et al. 2019; Du Plessis et al. 2014; Terjesen et al. 2009). We find a similar pattern in our data: Fig. 1 shows that average levels and linear trends of the ratio of women on boards differ between listed and state-owned companies. Such disparities have been explained by asserting that the presence of women in top positions reflects awareness of and responsiveness to wider social issues (Kelan 2008; Wang and Kelan 2013). The main argument here is that the ethos in the public sector is generally more receptive to social issues than in the private sector, and therefore also to gender equality (Brieger et al. 2019). Another explanation emphasizes variations in sub-national regulatory policies (Terjesen et al. 2009; Thams et al. 2018). Austria's Federal Equal Treatment Act initiated measures to support women at all levels of the civil service (Gresch and Sauer 2018), leading to less vertical and horizontal gender segregation in the public sector compared to private businesses. However, the act is only applicable to civil service jobs and does not cover state-owned companies. Nevertheless, we attribute the higher level of gender equality and positive trend in the ratio of women on the boards of state-owned compared to private companies to a moderate spillover effect from the Federal Equal Treatment Act. Due to these differences and the fact that the self-regulation measures are specific to the respective sets of companies, we analyze the two sets separately.

The following tables (Tables 2, 3, and 4) present the results of the repeated-measures Poisson regressions for the various predictors of female representation. In addition to the parameter estimates and standard errors for the predictors, the tables give the exponentiated regression coefficients (with 95\% confidence interval), which represent the estimated multiplicative effect of the predictor on the proportion of female board members. Here a parameter estimate of 2 implies that (keeping the other predictors constant) a one-unit increase in the predictor (the reported period after implementation compared to the period before) doubles the estimated proportion of female 
Table 1 Descriptive statistics and intercorrelations

\begin{tabular}{|c|c|c|c|c|c|c|c|c|c|c|c|c|}
\hline & Listed companies $^{\mathrm{a}}$ & Mean & SD & 1. & 2. & 3. & 4. & 5. & 6. & 7. & 8. & 9. \\
\hline 1. & $\%$ female directors & 8.77 & 12.54 & & & & & & & & & \\
\hline 2. & $n$ female directors & 0.67 & 0.92 & $0.97 * *$ & & & & & & & & \\
\hline 3. & Recommendation & 0.35 & 0.48 & 0.03 & 0.05 & & & & & & & \\
\hline 4. & Targets & $\mathrm{n} / \mathrm{a}$ & $\mathrm{n} / \mathrm{a}$ & - & - & - & & & & & & \\
\hline 5. & Threat & 0.47 & 0.50 & $0.24 * *$ & $0.23 * *$ & - & - & & & & & \\
\hline 6. & Year & 2010.4 & 3.07 & $0.33 * *$ & $0.36 * *$ & $0.84 * *$ & - & $0.89 * *$ & & & & \\
\hline 7. & Board size & 7.58 & 2.93 & $0.13 * *$ & $0.27 * *$ & 0.07 & - & 0.06 & $0.16^{* *}$ & & & \\
\hline 8. & Company size & 8.13 & 1.82 & -0.04 & 0.05 & 0.06 & - & 0.06 & $0.13 * *$ & $0.46^{* *}$ & & \\
\hline 9. & Board tenure & 11.22 & 3.63 & $-0.28 * *$ & $-0.30 * *$ & $-0.27 * *$ & - & $-0.35 * *$ & $-0.69 * *$ & $-0.16^{* *}$ & 0.03 & \\
\hline \multirow[t]{2}{*}{10.} & 'Female' industry & 0.47 & .50 & -0.04 & -0.04 & 0.03 & - & 0.04 & 0.07 & -0.02 & 0.10 & -0.02 \\
\hline & State-owned companies ${ }^{b}$ & Mean & SD & 1. & 2. & 3. & 4. & 5. & 6. & 7. & 8. & 9. \\
\hline 1. & $\%$ female directors & 22.53 & 19.45 & & & & & & & & & \\
\hline 2. & $n$ female directors & 1.70 & 1.55 & $0.90 * *$ & & & & & & & & \\
\hline 3. & Recommendation & $\mathrm{n} / \mathrm{a}$ & $\mathrm{n} / \mathrm{a}$ & - & - & & & & & & & \\
\hline 4. & Targets & 0.58 & .49 & $0.46 * *$ & $0.36^{* *}$ & - & & & & & & \\
\hline 5. & Threat & $\mathrm{n} / \mathrm{a}$ & $\mathrm{n} / \mathrm{a}$ & - & - & - & - & & & & & \\
\hline 6. & Year & 2011.2 & 3.07 & $0.50 * *$ & $0.38 * *$ & - & $0.86 * *$ & - & & & & \\
\hline 7. & Board size & 7.47 & 2.98 & $0.09 *$ & $0.45^{* *}$ & - & -0.07 & - & $-0.11 *$ & & & \\
\hline 8. & Company size & 4.76 & 2.07 & $0.11 *$ & $0.20 * *$ & - & -0.07 & - & -0.09 & $0.27 * *$ & & \\
\hline 9. & Board tenure & 9.92 & 3.49 & $-0.39 * *$ & $-0.32 * *$ & - & $-0.67 * *$ & - & $-0.77 * *$ & 0.02 & 0.06 & \\
\hline 10 & 'Female' industry & 0.50 & 0.50 & $0.13 * *$ & $0.14 * *$ & - & -0.01 & - & -0.01 & 0.06 & 0.02 & -0.08 \\
\hline
\end{tabular}

Spearman rank correlations; $* p<0.05, * * p<0.01$

${ }^{a} n=439$, except for Recommendation (237), Threat (157), Company size (399)

${ }^{\mathrm{b}} n=527$, except for Company size (445)

\section{Listed companies}

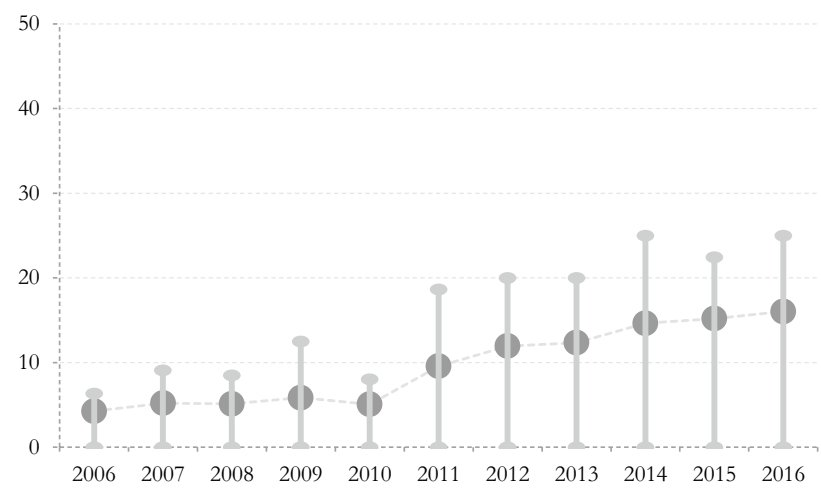

State-owned companies

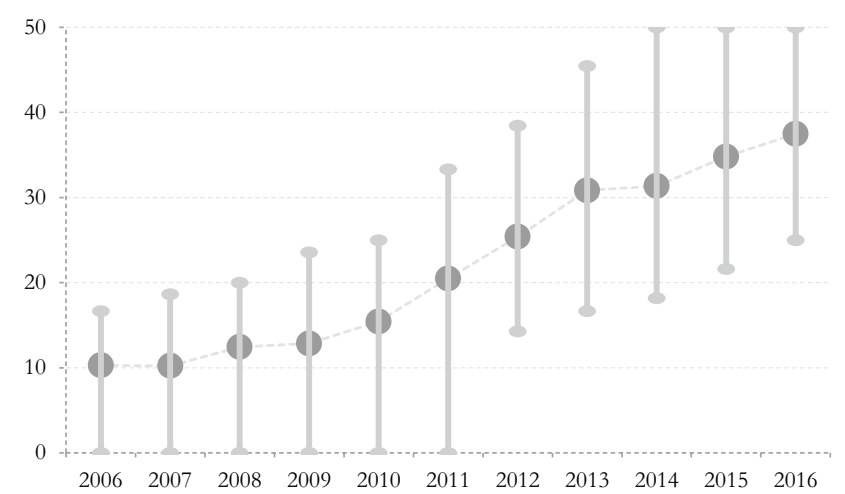

Fig. 1 Development of proportion of female board members in both samples

board members. Likewise, an estimate of .5 means that the proportion of female directors is halved.

There is no evidence for a positive effect of Recommendations. The results even indicate an insignificant negative effect (more so in smaller companies, as evidenced in the marginally significant interaction with board size).
Looking at the range of estimated effects of Recommendations covered by the $95 \%$ confidence interval, the upper bound translates into a small correlational effect of .11 (Bonett 2007, p. 255). Therefore, while the confidence interval extends slightly into the positive range, the results are 
Table 2 Results for recommendation

\begin{tabular}{|c|c|c|c|c|}
\hline & \multicolumn{2}{|c|}{ Model 1 (main effects) } & \multicolumn{2}{|c|}{ Model 2 (incl. interaction effects) } \\
\hline & B (s.e.) & $\operatorname{Exp}(B)(95 \% \mathrm{CI})$ & B (s.e.) & $\operatorname{Exp}(B)(95 \% \mathrm{CI})$ \\
\hline Constant & $-2.75(0.34)^{* *}$ & $0.06(0.03 \ldots 0.13)$ & $-2.99(0.48)^{* *}$ & $0.05(0.02 \ldots 0.13)$ \\
\hline Recommendation $^{\mathrm{a}}$ & $-0.03(0.16)$ & $0.97(0.71 \ldots 1.33)$ & $-0.23(0.49)$ & $0.79(0.31 \ldots 2.06)$ \\
\hline Year & $0.14(0.07) *$ & $1.15(1.01 \ldots 1.31)$ & $0.15(0.06)^{* *}$ & $1.16(1.04 \ldots 1.30)$ \\
\hline Board size & $0.04(0.03)$ & $1.04(0.98 \ldots 1.12)$ & $0.04(0.03)$ & $1.04(0.98 \ldots 1.11)$ \\
\hline Company size & $-0.04(0.11)$ & $0.96(0.78 \ldots 1.18)$ & $-0.03(0.10)$ & $0.97(0.79 \ldots 1.19)$ \\
\hline Board tenure & $0.07(0.04)^{\dagger}$ & $1.07(0.99 \ldots 1.15)$ & $0.12(0.06)$ & $1.13(1.01 \ldots 1.26)$ \\
\hline 'Female' industry & $0.06(0.39)$ & $1.06(0.49 \ldots 2.30)$ & $0.24(0.48)$ & $1.28(0.50 \ldots 3.24)$ \\
\hline Recommendation $\times$ board size & & & $0.05(0.03)^{\dagger}$ & $1.05(1.00 \ldots 1.10)$ \\
\hline Recommendation $\times$ company size & & & $0.05(0.06)$ & $1.05(0.93 \ldots 1.18)$ \\
\hline Recommendation $\times$ board tenure & & & $-0.02(0.06)$ & $0.98(0.88 \ldots 1.09)$ \\
\hline Recommendation $\times$ 'female' industry & & & $0.18(27)$ & $1.20(0.70 \ldots 2.04)$ \\
\hline
\end{tabular}

${ }^{\dagger} p<0.10 * p<0.05, * * p<0.01$

$n$ (level 1, level 2): 215 years, 58 companies

a2009-2010 versus 2006-2008, listed companies

Table 3 Results for targets

\begin{tabular}{|c|c|c|c|c|}
\hline & \multicolumn{2}{|c|}{ Model 1 (main effects) } & \multicolumn{2}{|c|}{ Model 2 (incl. interaction effects) } \\
\hline & B (s.e.) & $\operatorname{Exp}(B)(95 \%$ CI $)$ & B (s.e.) & $\operatorname{Exp}(B)(95 \%$ CI $)$ \\
\hline Constant & $-1.91(0.16)^{* *}$ & $0.15(0.11 \ldots 0.20)$ & $-1.21(0.40)^{* *}$ & $0.30(0.14 \ldots 0.65)$ \\
\hline Targets $^{\mathrm{a}}$ & $0.33(0.09)^{* *}$ & $1.39(1.16 \ldots 1.66)$ & $-0.28(0.36)$ & $0.76(0.38 \ldots 1.52)$ \\
\hline Year & $0.07(0.03)^{* *}$ & $1.07(1.02 \ldots 1.13)$ & $0.07(0.03)^{* *}$ & $1.07(1.02 \ldots 1.13)$ \\
\hline Board size & $-0.00(0.01)$ & $1.00(0.97 \ldots 1.03)$ & $0.03(0.02)$ & $1.03(0.99 \ldots 1.06)$ \\
\hline Company size & $-0.02(0.04)$ & $0.98(0.91 \ldots 1.06)$ & $0.04(0.07)$ & $1.04(0.90 \ldots 1.19)$ \\
\hline Board tenure & $-0.04(0.03)^{\dagger}$ & $0.96(0.91 \ldots 1.01)$ & $-0.08(0.05)$ & $0.93(0.83 \ldots 1.03)$ \\
\hline "Female" industry & $0.15(0.17)$ & $1.17(0.84 \ldots 1.62)$ & $0.33(0.23)$ & $1.39(0.89 \ldots 2.16)$ \\
\hline State ownership $75+$ to $100 \%$ & & & $-0.80(0.32)^{*}$ & $0.45(0.24 \ldots 0.84)$ \\
\hline State ownership $50+$ to $75 \%$ & & & $-0.78(0.49)$ & $0.46(0.18 \ldots 1.19)$ \\
\hline Targets $\times$ board size & & & $-0.03(0.02)^{*}$ & $0.97(0.94 \ldots 1.00)$ \\
\hline Targets $\times$ company size & & & $-0.05(0.06)$ & $0.95(0.85 \ldots 1.06)$ \\
\hline Targets $\times$ board tenure & & & $0.04(0.05)$ & $1.04(0.94 \ldots 1.15)$ \\
\hline Targets $\times$ 'female' industry & & & $-0.10(0.19)$ & $0.90(0.62 \ldots 1.32)$ \\
\hline Targets $\times$ state ownership $75+$ to $100 \%$ & & & $0.70(0.28)^{*}$ & $2.02(1.17 \ldots 3.49)$ \\
\hline Targets $\times$ state ownership $50+$ to $75 \%$ & & & $0.48(0.46)$ & $1.62(0.65 \ldots 4.01)$ \\
\hline
\end{tabular}

${ }^{\dagger} p<0.10 * p<0.05, * * p<0.01$

$n$ (level 1, level 2): 445/440 years, 59 companies

a2011-2016 versus 2006-2010, state-owned companies

largely in accordance with H1, negating a positive impact of Recommendations on gender diversity on boards.

Unlike Recommendations and in accordance with $\mathrm{H} 2$, Targets raise the proportion of female board members by an estimated factor of 1.4 even when the linear upward trend is accounted for. According to the results for model 2, this effect is strongest in companies with a high degree of public ownership (and weakest in companies with larger boards).
The results also show Threat as having a positive effect on the proportion of female board members (albeit less so in larger companies and/or boards with higher average tenure), supporting H3. On average, Threat increases the proportion of female board members by an estimated factor of 1.5, which is comparable to Targets. In addition, we found that after 2012, when the code provisions were included in an amendment to the Austrian Company Law but without mentioning any quotas, the threat of implementing a 
Table 4 Results for threat

\begin{tabular}{|c|c|c|c|c|}
\hline & \multicolumn{2}{|c|}{ Model 1 (main effects) } & \multicolumn{2}{|c|}{ Model 2 (incl. interaction effects) } \\
\hline & B (s.e.) & $\operatorname{Exp}(B)(95 \%$ CI $)$ & B (s.e.) & $\operatorname{Exp}(B)(95 \%$ CI $)$ \\
\hline Constant & $-2.30(0.29)^{* *}$ & $0.10(0.06 \ldots 0.18)$ & $-2.80(0.40)^{* *}$ & $0.06(0.03 \ldots 0.13)$ \\
\hline Threat $^{\mathrm{a}}$ & $0.40(0.17)^{*}$ & $1.49(1.06 \ldots 2.10)$ & $0.99(0.33)^{* *}$ & $2.69(1.42 \ldots 5.12)$ \\
\hline Year & $-0.05(0.08)$ & $0.95(0.82 \ldots 1.11)$ & $-0.01(0.07)$ & $0.99(0.87 \ldots 1.13)$ \\
\hline Board size & $-0.04(0.03)$ & $0.96(0.91 \ldots 1.02)$ & $-0.04(0.02)^{\dagger}$ & $0.96(0.93 \ldots 1.00)$ \\
\hline Company size & $-0.04(0.11)$ & $0.97(0.78 \ldots 1.20)$ & $0.20(0.14)$ & $1.22(0.93 \ldots 1.61)$ \\
\hline Board tenure & $-0.17(0.07)^{*}$ & $0.85(0.73 \ldots 0.98)$ & $-0.04(0.05)$ & $0.96(0.87 \ldots 1.05)$ \\
\hline 'Female' industry & $-0.64(0.42)$ & $0.53(0.23 \ldots 1.20)$ & $-0.82(0.49)^{\dagger}$ & $0.44(0.17 \ldots 1.15)$ \\
\hline Threat $\times$ board size & & & $0.02(0.03)$ & $1.02(0.96 \ldots 1.08)$ \\
\hline Threat $\times$ company size & & & $-0.22(0.10)^{*}$ & $0.80(0.65 \ldots 0.98)$ \\
\hline Threat $\times$ board tenure & & & $-0.12(0.05)^{*}$ & $0.89(0.81 \ldots 0.98)$ \\
\hline Threat $\times$ 'female' industry & & & $-0.00(0.36)$ & $1.00(0.49 \ldots 2.02)$ \\
\hline
\end{tabular}

${ }^{\dagger} p<0.10 * p<0.05, * * p<0.01$

$n$ (level 1, level 2): 153 years, 46 companies

a2011-2012 versus 2009-2010, listed companies

mandatory quota and its effect on the proportion of female directors had disappeared. Once the voluntary code provision was replaced by an unspecific legal prescription, the media discourse on a mandatory quota faded and expectation fell that such as quota law would be introduced. Comparing the period 2013-2016 to the Threat period (2011-2012), our data shows the exponentiated regression coefficient (with the same control variables as in all other models) for the "postthreat' period to be $.98(.85 \ldots 1.13)$, ns; the effect for year is $1.1(1.01 \ldots 1.19), p<.05$.

Poisson regression assumes mean and variance of the dependent count variable to be equal (see Coxe et al. 2009, p. 123). The observed variance-to-mean ratio for female board members in the models presented above is 1.5 for Targets and 1.2 for Recommendations and Threat, indicating a certain but not serious degree of overdispersion. In addition to using robust standard errors in the models presented above, we duplicated the analyses using a negative binomial distribution with virtually the same results and identical conclusions. Likewise, while the correlations between year and the self-regulations are considerable (see Table 1), the VIF values for all predictors are well below the commonly cited threshold of 10 (e.g., Wooldridge 2009, p. 99). Regarding the Hausman test mentioned in the section on data analysis, a comparison of the estimates of the three self-regulations with the level 2 variable (i.e., company) as a random effect to those with company as a fixed effect endorses the random effect models in all cases and does not indicate misspecification and/or endogeneity issues for the results presented above. Finally, we examined the effects of Recommendations, Targets, and Threat under the assumption that the regulations take effect with a delay of one year (i.e., 2010 vs. 2006-2008 for Recommendations, 2012-2016 vs. 2006-2010 for Targets, 2012 vs. 2009-2010 for Threat). Again, the estimates of the regulation effects lead to the same conclusions (for the results of all additional analyses, see "Appendix 2").

\section{Discussion}

Our findings indicate that self-regulation of gender diversity on boards is ineffective if merely based on recommendations in codes of good governance. Nominators appear skeptical of gains from gender-diverse boards, which also indicates that the overall societal demand for gender equality is too low to reward the abandonment of prevailing male-oriented nomination practices. Nevertheless, we found evidence for the effectiveness of self-regulation via code recommendations under particular conditions: Even in the absence of a sufficient number of early adopters to initiate pressures on non-adopters, self-regulation was effective when additional forces for compliance could be triggered. In the case of Austria, we showed that the threat of the regulator introducing mandatory quotas could reinforce nominators' motivation to comply, leading to an increased proportion of female directors in listed companies. We also found that for state-owned companies, self-regulation via a code recommendation was effective when supplemented by specific targets for outcomes and the public monitoring of fulfillment.

In the following subsections, we discuss conceptual as well as policy implications, and reflect on the limitations of our study as well as avenues for further research.

\section{'Opportunity Bias' of Codes Limits Potential for Gender-Diverse Boards}

Drawing on literature from institutional theory (Kennedy and Fiss 2009), we have argued that companies comply with 
code recommendations either because of expected benefits or the perceived danger associated with non-adoption. Yet our data shows that codes of good governance alone were insufficient to effectively promote gender-diverse boards.

Therefore, codes of good governance are not an apt means to implement gender-diverse boards unless supported by other forces. We believe that this can be explained by the mechanism underlying codes, which draws on a positive feedback loop initiated by early adopters causing bandwagon pressures on later adopters (Abrahamson and Rosenkopf 1993). Deviating companies then respond to those pressures as they do not wish to suffer competitive disadvantage from public exposure or blame for deviating from a code recommendation (Boyd 1996). Yet in our case, the number of early adopters failed to meet the adoption threshold.

For codes to be effective, a sufficient number of early adopters is required to initiate bandwagon pressures, which then increases with the number of adopters. However, in contrast to later adopters, who wish to avoid losses incurred by such pressures, early adopters need to be motivated by expected gains. Yet while gender equality may be societally demanded and, hence, socially expected to a certain extent (Perrault 2015; Terjesen et al. 2009), very few nominators expect to enjoy specific benefits from gender-diverse boards.

From a conceptual perspective, the mechanism of codes thus suffers from what we call an 'opportunity bias', as a sufficient number of adopters (motivated by expected gains) is needed to unfold the pressures described as central to its functioning. In the case of recommendations for gender-diverse boards, however, where nominators do not see a sufficient opportunity to achieve gains, additional forces must be triggered to ensure compliance. In sum, we can say that political goals such as gender equality originating from ethical rather than instrumental considerations are unlikely to be effectively implemented by means of codes of good governance alone.

\section{Policy Implications: Introduce Specific Targets, Threaten to Legislate Quotas}

Regulators around the world have turned to mandatory quotas to increase female representation on boards, believing voluntary self-regulation to be ineffective (Grosvold et al. 2007). In this study we have identified ways to improve the effectiveness of self-regulation for gender-diverse boards that draw on voluntary codes. For policy-makers, this implies two potential options to boost the impact of self-regulation: First, code issuers may focus on measurable outcomes by introducing targets to otherwise unspecific recommendations while publicly monitoring their fulfillment. Second, regulators should threaten companies with the imposition of mandatory quotas if self-regulation does not work. However, both approaches have some limitations:

\section{Targets: Drivers But Also Caps}

Our data shows that voluntary self-regulation via a code of good governance recommendation is effective when supported by specific targets. Such targets may, however, produce an unintended dysfunctional effect. While targets usually define objectives that should be met as closely as possible, in the case of gender diversity, targets set minimum standards that should eventually be exceeded in order to achieve gender equality on boards (i.e., equal representation of women and men). Equality requires a balance between women and men of at least 40:60 (Du Plessis et al. 2014; see also European Commission 2012). Yet targets for female representation specified in national code recommendations usually range between 30 and 35\% (Gabaldon et al. 2017a). Here we can identify a potential downside of the binary hit-or-miss logic of targets: As companies strive to meet but not exceed them, they function not merely as drivers for gender diversity but also as caps, which actually impede gender equality. Clearly, this potential side effect must be taken into account when setting gender targets.

\section{The Threat of Legislative Quotas: Credibility is the Key}

In our study, we have shown how recommendations in codes of good governance are rendered effective by the threat that the regulator might impose a mandatory quota. Drawing on the 'shadow of hierarchy' concept, we argue that such a threat only has the potential to impose pressures on nominators when credible, i.e., when they believe that the regulator is able and willing to legislate if self-regulation fails (Mayntz and Scharpf 1995; Héritier and Eckert 2008). In our case, the Austrian capital market accepted that the European Commission as well as the Austrian government were both willing and able to introduce mandatory quotas if self-regulation proved ineffective. However, there are also limits to this mechanism: It is difficult for regulators to keep a threat credible over time, as they have to constantly signal their willingness and capacity to deliver.

\section{Limitations of Our Study and Avenues for Future Research}

It has been shown that the societal demand for gender-diverse boards, in particular, and gender equality, in general, have increased around the world (Perrault 2015). The particular extent, however, varies across countries and cultural contexts (Brieger et al. 2019; Gregorič et al. 2017; Grosvold and Brammer 2011; Grosvold et al. 2016). Austria has been described as an example of a 'conservative gender regime' (Langan and Ostner 1991), i.e., a country with a strong welfare-state system that nevertheless supports a male-gendered 'breadwinner' model (Gresch and Sauer 2018). This results in unequal economic participation (World Economic Forum 2017) and limited career opportunities for women-a characteristic that 
Austria shares with many other gender-conservative countries such as Germany, France, or Italy (Bambra 2007; Langan and Ostner 1991). We believe, therefore, that although derived from the single case of Austria, our results provide insights into self-regulation for diverse boards in conservative gender contexts, in general, as well as in countries that in addition share other cultural features of Austria such as the regulatory tradition and corporate governance characteristics (e.g., Germany), in particular. Furthermore, we are convinced that our study implications are also relevant for contexts more favorable to gender-diverse boards than Austria: Here, we argue, targets and public monitoring as well as the threat of legislated quotas will additionally boost the ratio of women on boards. Future empirical studies could take a comparative cross-country perspective in order to confirm the generalizability and validity of our implications.

Even with boards becoming more gender-diverse or even gender-balanced (sometimes at the expense of other diversity dimensions: Gregorič et al. 2017), gender segregation may continue in more subtle forms such as in a persistent pay gap (Gregory-Smith et al. 2014) or the exclusion of female directors from strategically-relevant positions on board subcommittees (Rebérioux and Roudaut 2017). This can be interpreted as a sign that gender disparities do not necessarily disappear through increased female participation; instead they shift onto boards where women often hold less powerful and prestigious positions than their male co-directors (Harrison and Klein 2007). We thus see a need for further empirical studies to investigate the wider implications of voluntary self-regulation on gender equality, i.e., how it contributes to a cultural shift and changing gender roles within the boardroom and 'beyond' (Bertrand et al. 2019).

Recent literature has emphasized the fact that gender diversity on boards, in particular, and gender equality, in general, do not result from single measures but rather from an interplay of various activities (Brieger et al. 2019; Iannotta et al. 2016; Klettner et al. 2016), involving multiple actors such as policy-makers, companies, but also the wider public (Seierstad et al. 2017; while hardly comparable to other regulatory contexts, the UK has been described as pursuing such a 'multi-stakeholder approach'; see Doldor 2017). While self-regulation via codes of good governance has the potential to mobilize a variety of actors and activities, it nevertheless is merely a single measure whose overall impact is limited. Therefore, future research should focus on various efforts that, in concert, increase gender diversity.

\section{Conclusion}

While scholars have emphasized the potential of self-regulation for gender diversity on boards, many regulators have turned to mandatory quotas, believing voluntary codes to be ineffective. The aim of our study was to shed light on this dilemma. We sought to broaden our conceptual knowledge of how codes work in the specific case of gender diversity on boards. More specifically, we investigated the conditions under which self-regulation via codes can be effective. In answering our research question, we expanded recent institutional-theory perspectives on women on boards to consider the topic of self-regulation via codes of good governance. We showed that code recommendations in Austria have been ineffective unless supported by other forces. In particular, we found that the inclusion of specific targets for the proportion of female directors and the threat of legislated quotas can serve to pressurize nominators, resulting in more genderdiverse company boards. The contribution of our study to the ongoing discourse around women on boards is threefold. First, we give an empirical account of the conditions under which the self-regulation of gender diversity on boards via codes of good governance is effective. Second, we identify two potential ways of boosting the impact of voluntary selfregulation for gender-diverse boards. Third, and perhaps of greatest interest, we argue that codes of good governance suffer from what we call an 'opportunity bias', i.e., their underlying mechanisms require a sufficient number of companies to implement a practice because of expected gains, thereby initiating pressures on non-adopters. However, this is not currently the case regarding gender-diverse boards. Therefore, we conclude that political goals such as gender equality based on ethical rather than instrumental considerations are unlikely to be effectively implemented by codes alone.

Acknowledgements Open access funding provided by Vienna University of Economics and Business (WU). The authors wish to thank the following scholars for their invaluable feedback: Claudio Biscaro, Giuseppe Delmestri, Dennis Jancsary, Katharina Pernkopf, Mia Raynard, and Daniel Semper, who participated in the Department of Management's Writing Club at WU Vienna, as well as Johanne Grosvold and Alessandro Zattoni, who discussed the manuscript at the PDW 'On-Boarding Diversity in Corporate Boards Research: A Paper Development Workshop' at the Academy of Management Annual Meeting 2018.

\section{Compliance with Ethical Standards}

Conflict of interest The authors declare that they have no conflict of interest.

Open Access This article is distributed under the terms of the Creative Commons Attribution 4.0 International License (http://creativeco mmons.org/licenses/by/4.0/), which permits unrestricted use, distribution, and reproduction in any medium, provided you give appropriate credit to the original author(s) and the source, provide a link to the Creative Commons license, and indicate if changes were made. 


\section{Appendix}

\section{Appendix 1}

See Fig. 2.

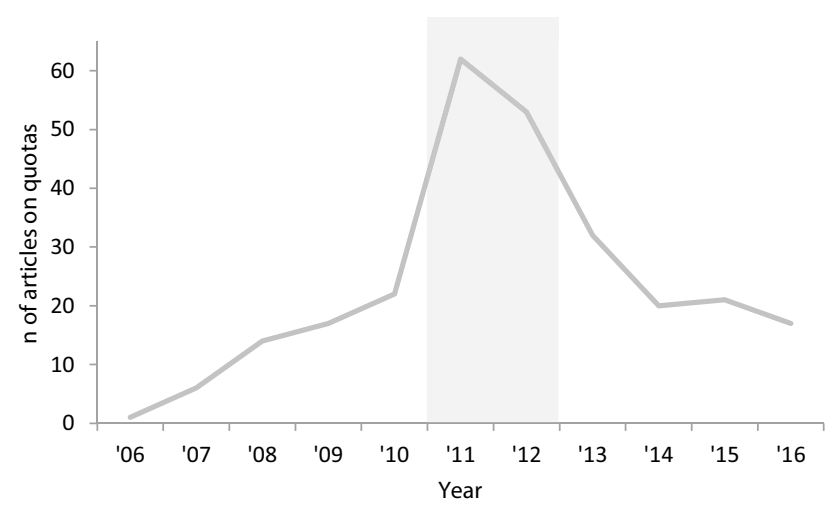

Fig. 2 Threat as period of intense debate on quota implementation. 137 newspaper articles on the implementation of mandatory quotas were published from 2010 to 2012 by the leading Austrian newspapers Der Standard (left-of-center) and Die Presse (right-of-center)

\section{Appendix 2}

See Table 5 .

Table 5 Robustness checks, VIF values and Hausman endogeneity test for the three self-regulations

\begin{tabular}{|c|c|c|c|c|c|}
\hline & \multicolumn{2}{|c|}{ Negative binomial model } & \multicolumn{2}{|c|}{ One year time lag } & \multirow[t]{2}{*}{ VIF value } \\
\hline & B (s.e.) & $\operatorname{Exp}(B)(95 \%$ CI $)$ & B (s.e.) & $\operatorname{Exp}(B)(95 \% C I)$ & \\
\hline Constant & $-2.69(0.36)^{* *}$ & $0.07(0.03 \ldots 0.14)$ & $-2.50(0.46)^{* *}$ & $0.08(0.03 \ldots 0.20)$ & \\
\hline Recommendation & $-0.05(0.18)$ & $0.96(0.67 \ldots 1.35)$ & $-0.30(0.22)$ & $0.74(0.49 \ldots 1.14)$ & 3.68 \\
\hline Year & $0.13(0.07)^{\dagger}$ & $1.14(1.00 \ldots 1.30)$ & $0.20(0.08)^{*}$ & $1.22(1.04 \ldots 1.43)$ & 3.91 \\
\hline Board size & $0.04(0.03)$ & $1.05(0.98 \ldots 1.12)$ & $0.05(0.03)^{\dagger}$ & $1.05(1.00 \ldots 1.11)$ & 1.47 \\
\hline Company size & $-0.06(0.10)$ & $0.94(0.78 \ldots 1.14)$ & $-0.09(0.10)$ & $0.92(0.75 \ldots 1.12)$ & 1.52 \\
\hline Board tenure & $0.07(0.04)^{\dagger}$ & $1.07(1.00 \ldots 1.16)$ & $-0.07(0.04)^{\dagger}$ & $1.07(1.00 \ldots 1.16)$ & 1.21 \\
\hline 'Female' industry & $-0.02(0.41)$ & $0.98(0.44 \ldots 2.16)$ & $0.22(0.44)$ & $1.25(0.53 \ldots 2.93)$ & 1.08 \\
\hline Hausman test & \multicolumn{2}{|c|}{ Random effects model } & \multicolumn{2}{|c|}{ Fixed effects model } & $\chi^{2}$ value \\
\hline \multirow[t]{3}{*}{ Recommendation } & $-0.01(0.17)$ & $.99(0.71 \ldots 1.37)$ & $-0.05(0.15)$ & $0.95(0.71 \ldots 1.27)$ & $0.20(p=0.65)$ \\
\hline & \multicolumn{2}{|c|}{ Negative binomial model } & \multicolumn{2}{|c|}{ One year time lag } & VIF value \\
\hline & B (s.e.) & $\operatorname{Exp}(B)(95 \%$ CI $)$ & B (s.e.) & $\operatorname{Exp}(B)(95 \%$ CI $)$ & \\
\hline Constant & $-1.97(0.18)^{* *}$ & $0.14(0.10 \ldots 0.20)$ & $-1.92(0.17)^{* *}$ & $0.15(0.11 \ldots 0.20)$ & \\
\hline Targets & $0.34(0.09)^{* *}$ & $1.40(1.17 \ldots 1.67)$ & $0.38(0.12)^{* *}$ & $1.47(1.16 \ldots 1.85)$ & 3.90 \\
\hline Year & $0.06(0.03) *$ & $1.06(1.00 \ldots 1.12)$ & $0.07(0.03) *$ & $1.07(1.01 \ldots 1.13)$ & 5.33 \\
\hline Board size & $0.00(0.01)$ & $1.00(0.97 \ldots 1.03)$ & $-0.01(0.01)$ & $0.99(0.97 \ldots 1.01)$ & 1.22 \\
\hline Company size & $0.01(0.04)$ & $1.01(0.93 \ldots 1.10)$ & $-0.01(0.04)$ & $0.99(0.92 \ldots 1.07)$ & 1.18 \\
\hline Board tenure & $-0.07(0.03) *$ & $0.93(0.88 \ldots 0.99)$ & $-0.04(0.03)$ & $0.97(0.92 \ldots 1.02)$ & 2.24 \\
\hline 'Female' industry & $0.27(0.17)$ & $1.31(0.93 \ldots 1.83)$ & $0.18(0.16)$ & $1.19(0.86 \ldots 1.64)$ & 1.05 \\
\hline
\end{tabular}


Table 5 (continued)

\begin{tabular}{|c|c|c|c|c|c|}
\hline \multirow{2}{*}{$\begin{array}{l}\text { Hausman test } \\
\text { Targets }\end{array}$} & \multicolumn{2}{|c|}{ Random effects model } & \multicolumn{2}{|c|}{ Fixed effects model } & \multirow{2}{*}{$\begin{array}{l}\chi^{2} \text { value } \\
0.01(p=0.91)\end{array}$} \\
\hline & $0.30 .(09)^{* *}$ & $1.35(1.13 \ldots 1.62)$ & $.30(0.07)^{* *}$ & $1.35(1.16 \ldots 1.57)$ & \\
\hline & \multicolumn{2}{|c|}{ Negative binomial model } & \multicolumn{2}{|l|}{ One year time lag } & \multirow[t]{2}{*}{ VIF value } \\
\hline & B (s.e.) & $\operatorname{Exp}(B)(95 \%$ CI $)$ & B (s.e.) & $\operatorname{Exp}(B)(95 \%$ CI $)$ & \\
\hline Constant & $-2.42(0.27)^{* *}$ & $0.09(0.05 \ldots 0.15)$ & $-2.62(0.31)^{* *}$ & $0.07(0.04 \ldots 0.13)$ & \\
\hline Threat & $0.39(0.18) *$ & $1.48(1.04 \ldots 2.10)$ & $.72(0.27)^{* *}$ & $2.05(1.21 \ldots 3.50)$ & 5.16 \\
\hline Year & $-0.02(0.08)$ & $0.98(0.84 \ldots 1.14)$ & $-0.16(0.12)$ & $0.85(0.68 \ldots 1.07)$ & 5.22 \\
\hline Board size & $-0.03(0.03)$ & $0.97(0.92 \ldots 1.02)$ & $-0.07(0.03) *$ & $0.93(0.87 \ldots 1.00)$ & 1.76 \\
\hline Company size & $0.05(0.11)$ & $1.05(0.85 \ldots 1.30)$ & $0.07(0.12)$ & $1.07(0.85 \ldots 1.35)$ & 1.72 \\
\hline Board tenure & $-0.14(0.07)^{\dagger}$ & $0.87(0.75 \ldots 1.00)$ & $-0.14(0.07) *$ & $0.87(0.76 \ldots 1.00)$ & 1.24 \\
\hline 'Female' industry & $-0.60(0.35)^{\dagger}$ & $0.55(0.28 \ldots 1.09)$ & $-0.59(0.38)$ & $0.56(0.27 \ldots 1.16)$ & 1.11 \\
\hline Hausman test & \multicolumn{2}{|c|}{ Random effects model } & \multicolumn{2}{|c|}{ Fixed effects model } & $\chi^{2}$ value \\
\hline Threat & $0.48(0.18)^{* *}$ & $1.61(1.13 \ldots 2.29)$ & $0.40(0.22)^{\dagger}$ & $1.49(0.97 \ldots 2.28)$ & $0.41(p=0.52)$ \\
\hline
\end{tabular}

${ }^{\dagger} p<0.10, * p<0.05, * * p<0.01$

\section{References}

Abrahamson, E., \& Rosenkopf, L. (1993). Institutional and competitive bandwagons: Using mathematical modeling as a tool to explore innovation diffusion. Academy of Management Review, 18(3), 487-517.

Adams, R. B., de Haan, J., Terjesen, S., \& van Ees, H. (2015). Board diversity: Moving the field forward. Corporate Governance: An International Review, 23(2), 77-82.

Agresti, A. (2007). An introduction to categorical data analysis (2nd ed.). Hoboken: Wiley.

Aguilera, R., \& Cuervo-Cazurra, A. (2004). Codes of good governance worldwide: What is the trigger? Organization Studies, 25(3), 415-443.

Aguilera, R., \& Cuervo-Cazurra, A. (2009). Codes of good governance. Corporate Governance: An International Review, 17(3), 376-387.

Antonakis, J., Bendahan, S., Jacquart, P., \& Lalive, R. (2010). On making causal claims: A review and recommendations. The Leadership Quarterly, 21(6), 1086-1120.

Ashford, S. J., \& de Stobbeleir, K. E. M. (2013). Feedback, goal setting, and task performance revisited. In E. A. Locke \& G. P. Latham (Eds.), New developments in goal setting and task performance (pp. 51-64). New York: Routledge.

Bambra, C. (2007). Defamilisation and welfare state regimes: A cluster analysis. International Journal of Social welfare, 16(4), 326-338.

Bertrand, M., Black, S. E., Jensen, S., \& Lleras-Muney, A. (2019). Breaking the glass ceiling? The effect of board quotas on female labour market outcomes in Norway. Review of Economic Studies, 86(1), 191-239.

Bohman, L., Bygren, M., \& Edling, C. (2012). Surge under threat: The rapid increase of women on Swedish board of directors. In C. Fangan, M. C. González Menéndez \& S. Gómez Ansón (Eds.), Women on corporate boards and in top management: European trends and policy (pp. 91-108). New York: Palgrave Macmillan

Bonett, D. G. (2007). Transforming odds ratios into correlations for meta-analytic research. American Psychologist, 62(3), 254-255.

Börzel, T. A. (2008). Der, Schatten der Hierarchie': Ein GovernanceParadox? In G. F. Schuppert \& M. Zürn (Eds.), Governance in einer sich wandelnden Welt (pp. 118-131). Wiesbaden: VS.
Boyd, C. (1996). Ethics and corporate governance: The issues raised by the Cadbury report in the United Kingdom. Journal of Business Ethics, 15(2), 167-182.

Brieger, S. A., Francoeur, C., welzel, C., \& Ben-Amar, w. (2019). Empowering women: The role of emancipative forces in board gender diversity. Journal of Business Ethics, 155(2), 495-511.

Bundeskanzleramt. (2012). Public Corporate Governance Kodex: Grundsätze der Unternehmens- und Beteiligungsführung im Bereich des Bundes. https://www.kunstkultur.bka.gv.at/docum ents/340047/618530/Public+Corporate+Governance+Kodex/ f10d4434-3c7b-41e9-8aa3-bb6f068fee88.

Carrasco, A., Francoeur, C., Labelle, R., Laffarga, J., \& Ruiz-Barbadillo, E. (2015). Appointing women to boards: Is there a cultural bias? Journal of Business Ethics, 129(2), 429-444.

Coxe, S., west, S. G., \& Aiken, L. S. (2009). The analysis of count data: A gentle introduction to Poisson regression and its alternatives. Journal of Personality Assessment, 91(2), 121-136.

Davies, P. L. (2000). Board structure in the UK and Germany: Convergence or continuing divergence? International and Comparative Corporate Law Journal, 2(4), 435-456.

Deutscher Bundestag. (2014). Entwurf eines Gesetzes für die gleichberechtigte Teilhabe von Frauen und Männern an Führungspositionen in der Privatwirtschaft und im öffentlichen Dienst. https:// www.bmfsfj.de/blob/119354/4c698e0a4465ac49da33dd93936972 38/fuehrungsposition-data.pdf.

DiMaggio, P. J., \& Powell, ww. (1983). The iron cage revisited: Institutional isomorphism and collective rationality in organizational fields. American Social Review, 48(2), 147-160.

Doldor, E. (2017). UK: The merits and shortcomings of a voluntary approach. In C. Seierstad, P. Gabaldon, \& H. Mensi-Klarbach (Eds.), Gender diversity in the boardroom, volume 2: Multiple approaches beyond quotas (pp. 13-44). Cham: Palgrave Macmillan.

Doralt, P., Nowotny, C., \& Kalss, S. (2012). Kommentar zum Aktiengesetz. Wien: Linde.

Drucker, P. F. (1954). The practice of management. New York: Harper and Row.

Du Plessis, J., O'Sullivan, J., \& Rentschler, R. (2014). Multiple layers of gender diversity on corporate boards: To force or not to force? Deakin Law Review, 19(1), 1-50. 
Edelman, L. (2016). Working law: Courts, corporations and symbolic civil rights. Chicago: The University of Chicago Press.

European Commission. (2010). Giving Europe a female touch: European Commission adopts new strategy on gender equality. http:// europa.eu/rapid/press-release_IP-10-1149_en.htm.

European Commission. (2012). Women on boards: Commission proposes $40 \%$ objective. http://europa.eu/rapid/press-relea se IP-12-1205 en.htm.

European Commission. (2016). Gender balance on corporate boards: Europe is cracking the glass ceiling. Factsheet, July 2016. http:// ec.europa.eu/justice/gender-equality/files/gender_balance_decis ion_making/1607_factsheet_final_wob_data_en.pdf.

European Parliament. (2011). European Parliament resolution of 6 July 2011 on women and business leadership. http:// www.europarl.europa.eu/sides/getDoc.do?pubRef=-//EP// TEXT+TA+P7-TA-2011-0330+0+DOC+XML+V0//EN.

European Women's Lobby. (2012). Women on boards in Europe: From a snail's pace to a giant leap? EWL Report on progress, gaps and good practice. https://www.womenlobby.org/IMG/pdf/ewl_repor t_women_on_boards_in_europe_27_february-2.pdf.

Ferreira, D. (2015). Board diversity: Should we trust research to inform policy? Corporate Governance: An International Review, 23(2), 108-111.

Gabaldon, P., Mensi-Klarbach, H., \& Seierstad, C. (2017a). Gender diversity in the boardroom: The multiple versions of quota laws in Europe. In C. Seierstad, P. Gabaldon, \& H. Mensi-Klarbach (Eds.), Gender diversity in the boardroom, first volume: The use of different quota regulations (pp. 233-254). Cham: Palgrave Macmillan.

Gabaldon, P., Mensi-Klarbach, H., \& Seierstad, C. (2017b). Gender diversity in the boardroom: The multiple approaches beyond quota regulations. In C. Seierstad, P. Gabaldon, \& H. Mensi-Klarbach (Eds.), Gender diversity in the boardroom, second volume: Multiple approaches beyond quotas (pp. 261-284). Cham: Palgrave Macmillan

Gregorič, A., Oxelheim, L., Randøy, T., \& Thomsen, S. (2017). Resistance to change in the corporate elite: Female directors' appointments onto Nordic boards. Journal of Business Ethics, 141(2), 267-287.

Gregory-Smith, I., Main, B. G., \& O’Reilly, C. A., III. (2014). Appointments, pay and performance in UK boardrooms by gender. The Economic Journal, 124(574), F109-F128.

Gresch, N., \& Sauer, B. (2018). The Austrian paradox: The challenges of transforming a conservative gender regime. In E. Lépinard \& R. Rubio-Marín (Eds.), Transforming gender citizenship: The irresistible rise of gender quotas in Europe (pp. 308-338). Cambridge: Cambridge University Press

Grosvold, J., \& Brammer, S. (2011). National institutional systems as antecedents of female board representation: An empirical study. Corporate Governance: An International Review, 19(2), 116-135.

Grosvold, J., Brammer, S., \& Rayton, B. (2007). Board diversity in the United Kingdom and Norway: An exploratory analysis. Business Ethics: A European Review, 16(4), 334-357.

Grosvold, J., Rayton, B., \& Brammer, S. (2016). Women on corporate boards: A comparative institutional analysis. Business and Society, 55(8), 1157-1196.

Harrison, D. A., \& Klein, K. J. (2007). what's the difference? Diversity constructs as separation, variety, or disparity in organizations. Academy of Management Review, 32(4), 1199-1228.

Hart, S. M. (2010). Self-regulation, corporate social responsibility, and the business case: Do they work in achieving workplace equality and safety? Journal of Business Ethics, 92(4), 585-600.

Héritier, A., \& Eckert, S. (2008). New modes of governance in the shadow of hierarchy: Self-regulation by industry in Europe. Journal of Public Policy, 28(1), 113-138.
Héritier, A., \& Lehmkuhl, D. (2008). The shadow of hierarchy and new modes of governance. Journal of Public Policy, 28(1), 1-17.

Hillman, A. J., Shropshire, C., \& Cannella, A. A. (2007). Organizational predictors of women on corporate boards. Academy of Management Journal, 50(4), 941-952.

Höllerer, M. A. (2013). From taken-for-granted to explicit commitment: The rise of CSR in a corporatist country. Journal of Management Studies, 50(4), 573-606.

Iannotta, M., Gatti, M., \& Huse, M. (2016). Institutional complementaries and gender diversity on boards: A configurational approach. Corporate Governance: An International Review, 24(4), 406-427.

Ingram, P., \& Simons, T. (1995). Institutional and resource dependence determinants of responsiveness to work-family issues. Academy of Management Journal, 38(5), 1466-1482.

Jewson, N., \& Mason, D. (1986). The theory and practice of equal opportunities policies: Liberal and radical approaches. The Sociological Review, 43(2), 307-334.

Kelan, E. K. (2008). The discursive construction of gender in contemporary management literature. Journal of Business Ethics, 18(2), 427-445.

Kennedy, M.T., \& Fiss, P.C. (2009). Institutionalization, framing, and diffusion: The logic of TQM adoption and implementation decisions among U.S. hospitals. Academy of Management Journal, 52(5), 897-918.

Kirsch, A. (2017). The gender composition of corporate boards: A review and research agenda. The Leadership Quarterly, 29(2), 346-364.

Klettner, A., Clarke, T., \& Boersma, M. (2016). Strategic and regulatory approaches to increasing women in leadership: Multilevel targets and mandatory quotas as levers for cultural change. Journal of Business Ethics, 133(3), 395-419.

Labelle, R., Francoeur, C., \& Lakhal, F. (2015). To regulate or not to regulate? Early evidence on the means used around the world to promote gender diversity in the boardroom. Gender, Work and Organization, 22(4), 339-363.

Langan, M., \& Ostner, I. (1991). Geschlechterpolitik im Wohlfahrtsstaat: Aspekte im internationalen Vergleich. Kritische Justiz, 24(3), 302-317.

Locke, E. A. (1968). Toward a theory of task motivation and incentives. Organizational Behavior and Human Performance, 3(2), 157-189.

Locke, E. A., \& Latham, G. P. (2002). Building a practically useful theory of goal setting and task motivation: A 35-year odyssey. American Psychologist, 57(9), 705-717.

Locke, E. A., \& Latham, G. P. (2013). Goal setting theory: The current state. In E. A. Locke \& G. P. Latham (Eds.), New developments in goal setting and task performance (pp. 623-630). New York: Routledge.

Lounsbury, M. (2007). A tale of two cities: Competing logics and practice variation in the professionalizing of mutual funds. Academy of Management Journal, 50(2), 289-307.

Mayntz, R. (2006). Governance theory als fortentwickelte Steuerungstheorie? In G. F. Schuppert (Ed.), Governance-Forschung: Vergewisserung über Stand und Entwicklungslinien (pp. 11-20). Baden-Baden: Nomos.

Mayntz, R., \& Scharpf, F. W. (1995). Steuerung und Selbstorganisation in staatsnahen Sektoren. In R. Mayntz and F. W. Scharpf (Eds.), Gesellschaftliche Selbstregelung und Steuerung (pp. 39-72). Campus: Frankfurt a. M., New York.

Mensi-Klarbach, H. (2017). Gender diversity in Austrian boards: Combining soft and hard law regulations. In C. Seierstad, P. Gabaldon, $\& \mathrm{H}$. Mensi-Klarbach (Eds.), Gender diversity in the boardroom, volume 2: Multiple approaches beyond quotas (pp. 103-128). Cham: Palgrave Macmillan.

Mensi-Klarbach, H., \& Seierstad, C. (2019). Gender quotas on corporate boards: Similarities and differences in quota 
scenarios. European Management Review. https://doi. org/10.1111/emre.12374.

Mento, A. J., Steel, R. P., \& Karren, R. J. (1987). A meta-analytic study of the effects of goal setting on task performance: 1966-1984. Organizational Behavior and Human Decision Processes, 39(1), 52-83.

Meyer, R. E. (2004). Globale Managementkonzepte und lokaler Kontext: Organisationale Wertorientierung im österreichischen öffentlichen Diskurs. Wien: WUV.

Österreichische Bundesregierung. (2011). Vortrag an den Ministerrat: Erhöhung des Frauenanteils in den Aufsichtsgremien der Unternehmen mit einem Bundesanteil von $50 \%$ und darüber. http://www.oesta.gv.at/DocView.axd?CobId=43056.

Perrault, E. (2015). Why does board gender diversity matter and how do we get there? The role of shareholder activism in deinstitutionalizing old boys' networks. Journal of Business Ethics, 128(1), 149-165.

Peters, B. G., \& Pierre, J. (2016). Comparative governance: Rediscovering the functional dimension of governing. Cambridge: Cambridge University Press.

Post, C., \& Byron, K. (2015). women on boards and firm financial performance: A meta-analysis. Academy of Management Journal, 58(5), 1546-1571.

Rebérioux, A., \& Roudaut, G. (2017). Gender quota and inequalities inside the boardroom. hal-01618949. https://hal-polytechnique. archives-ouvertes.fr/hal-01618949/document.

Rhodes, R. A. W. (1996). The new governance: Governing without government. Political Studies, 44(4), 652-667.

Scharpf, F. W. (1997). Games real actors play: Actor-centered institutionalism in policy research. Boulder: Westview Press.

Schenz, R., \& Eberhartinger, M. (2002). Die Weiterentwicklung des Österreichischen Corporate Governance Kodex. In R. Schenz \& M. Eberhartinger (Eds.), Corporate Governance in Österreich: Zum 10-jährigen Bestehen des Österreichischen Corporate Governance Kodex (pp. 29-60). Wien: Bank.

Schuppert, G. F. (2007). Was ist und wozu Governance?. Berlin: Duncker und Humblot.

Sealy, R., and Vinnicombe, S. (2013). The female FTSE board report 2013: False dawn of progress for women on boards? Cranfield University, School of Management. http://dspace.lib.cranfield. ac.uk/handle/1826/8005.

Seidl, D. (2007). Standard setting and following in corporate governance: An observation-theoretical study of the effectiveness of governance codes. Organization, 14(5), 705-727.

Seierstad, C., \& Opsahl, T. (2011). For the few not the many? The effects of affirmative action on presence, prominence, and social capital of women directors in Norway. Scandinavian Journal of Management, 27(1), 44-54.

Seierstad, C., Warner-Søderholm, G., Torchia, M., \& Huse, M. (2017). Increasing the number of women on boards: The role of actors and processes. Journal of Business Ethics, 141(2), 289-315.

Singh, V., Point, S., \& Moulin, Y. (2015). French supervisory board gender composition and quota threat: Changes from 2008 to 2010. Gender in Management: An International Journal, 30(7), $551-571$
Smith, N. (2014). Quota regulations of gender composition on boards of directors. CESifo DICE Report, 12(2), 42-48.

Sojo, V. E., wood, R. E., wood, S. A., \& wheeler, M. A. (2016). Reporting requirements, targets, and quotas for women in leadership. The Leadership Quarterly, 27(3), 519-536.

Sozialversicherung. (2016). Statistische Daten aus der Sozialversicherung: Beschäftigte in Österreich. http://www.hauptverband.at/ cdscontent/?contentid=10007.693676\&portal=hvbportal\&viewm ode $=$ content.

Staub, K. E. (2009). Simple tests for exogeneity of a binary explanatory variable in count data regression models. Communications in Statistics: Simulation and Computation, 38(9), 1834-1855.

Staw, B. M., \& Epstein, L. D. (2000). what bandwagons bring: Effects of popular management techniques on corporate performance, reputation, and CEO pay. Administrative Science Quarterly, 45(3), 523-556.

Stein, A., \& van der Vlies, R. (2014). The commission proposal for improving gender balance in company boards. In M. de Vos \& P. Culliford (Eds.), Gender quotas for company boards (pp. 57-82). Cambridge: Intersentia.

Steurer, R. (2013). Disentangling governance: A synoptic view of regulation by government, business and civil society. Policy Sciences, 46(4), 387-410.

Terjesen, S., Aguilera, R., \& Lorenz, R. (2015). Legislating a woman's seat on the board: Institutional factors driving gender quotas for boards of directors. Journal of Business Ethics, 128(2), 233-251.

Terjesen, S., Sealy, R., \& Singh, V. (2009). Women directors on corporate boards: A review and research agenda. Corporate Governance: An International Review, 17(3), 320-337.

Thams, Y., Bendell, B. L., \& Terjesen, S. (2018). Explaining women's presence on corporate boards: The institutionalization of progressive gender-related policies. Journal of Business Research, 86, 130-140.

Tolbert, P. S., \& Zucker, L. G. (1983). Institutional sources of change in the formal structure of organizations: The diffusion of civil service reform, 1880-1935. Administrative Science Quarterly, 28, 22-39.

Wang, M., \& Kelan, E. (2013). The gender quota and female leadership: Effects of the Norwegian gender quota on board chairs and CEOs. Journal of Business Ethics, 117(3), 449-466.

Williams, R. L. (2000). A note on robust variance estimation for cluster-correlated data. Biometrics, 56(2), 645-646.

Wood, R. E., Whelan, J., Sojo, V., \& Wong, M. (2013). Goals, goal orientations, strategies, and performance. In E. A. Locke \& G. P. Latham (Eds.), New developments in goal setting and task performance (pp. 90-114). New York: Routledge.

Wooldridge, J. M. (2009). Introductory econometrics: A modern approach (4th ed.). Mason: Cengage Learning.

World Economic Forum. (2017). The global gender gap report 2017. http://www3.weforum.org/docs/WEF_GGGR_2017.pdf.

Zeger, S. L., \& Liang, K. Y. (1986). Longitudinal data analysis for discrete and continuous outcomes. Biometrics, 42(1), 121-130.

Publisher's Note Springer Nature remains neutral with regard to jurisdictional claims in published maps and institutional affiliations. 